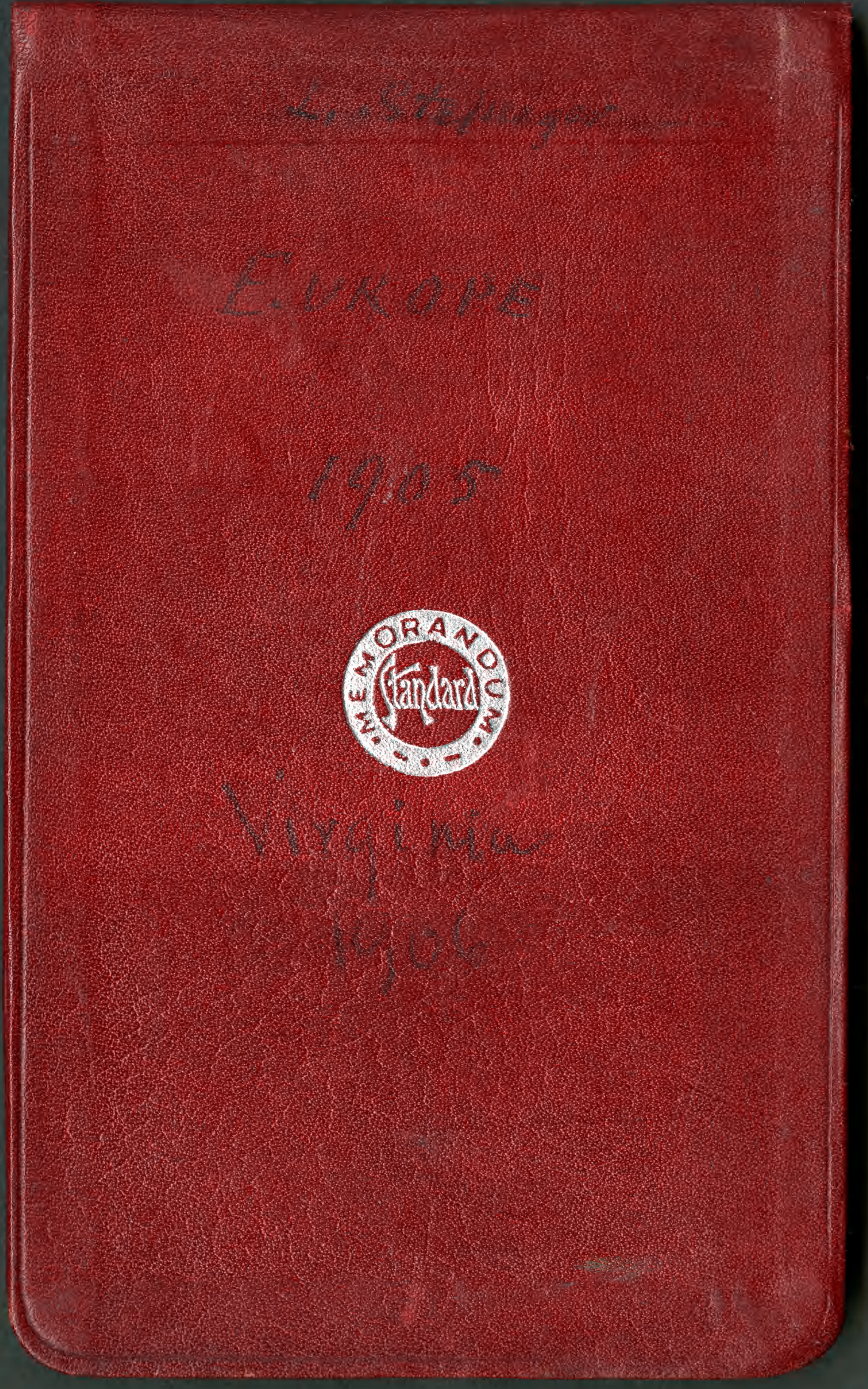




to oIII

ans.

Nysted harbov, waters colge, Collang. Tl. 116 men; tad, 38 ; hinef. 13

0112

oal.

Nysto havbor, wates wy, Udiland Je. III man, fail, 38 , hiadf. 13.5

0113 Ecotomyp Jad. Rra) alon Aalhow paste mess

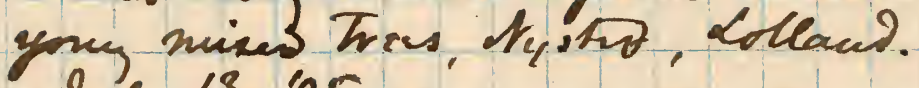
Tl. 153 men; tail, 51 ; hinsf. 18 0114 Suotoney
ord beach wood natte of jow. Nastid Lollaw, Stumate Jule 14 os Te. 12 man; thil, 35 ; hing 7. 18 


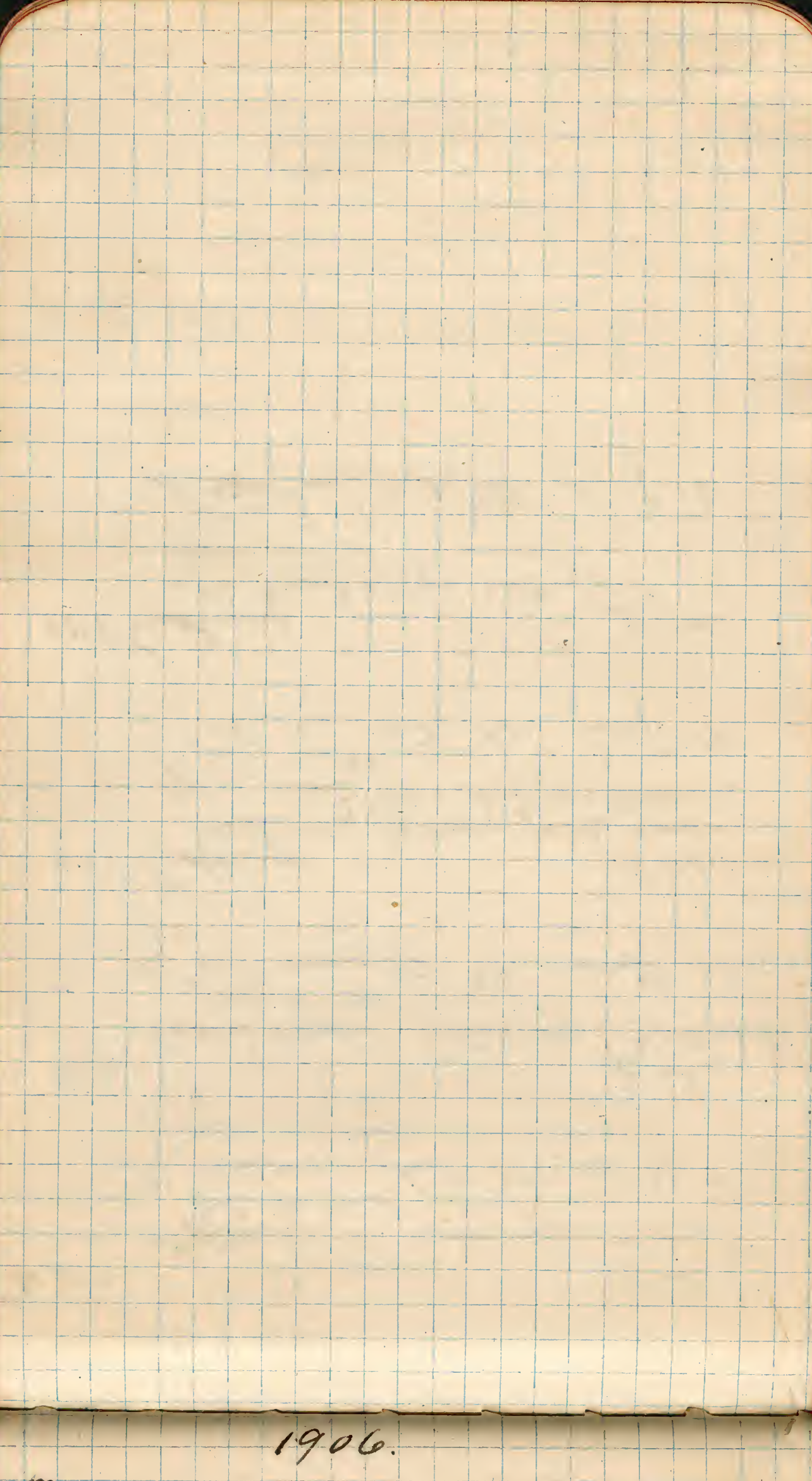
no

ONS - Rarophis punctatus - ful 17 of

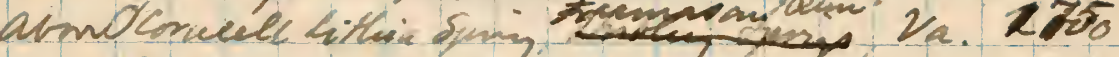
Colos abon daik onotey opn (de) top if neal alive, collar oranige-4mff;

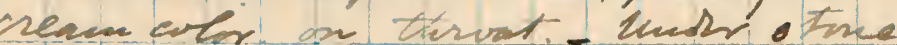

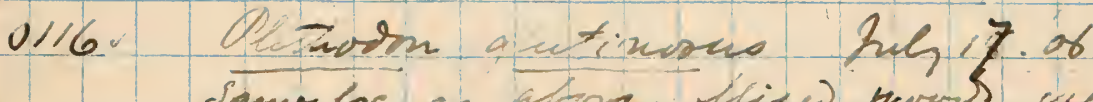
same loc.er atone: Lixis thes pine cke suess otme

elin bluis blade nith "eace gray pecks; nurmuath slate color, billy wite a ohm purplier wash; teroat,

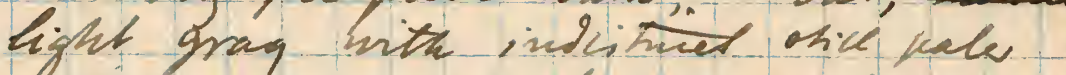
outs; ustrmide of hans as pech as will as wut diet pele gray.

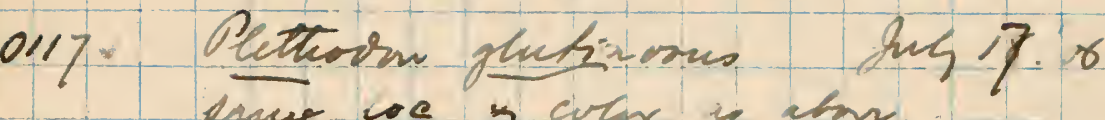

0118 Dronozncther duls 19.6. Breis refferond Tremesan Rum, near diside

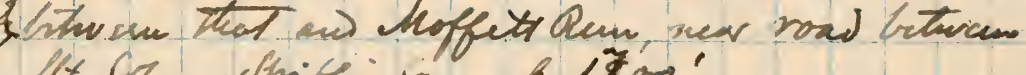
At. Snon x Smitain opr. ab. IYoo Aton "raw icmua" ith a osvis of findisfinet large mand oposs of tawny.

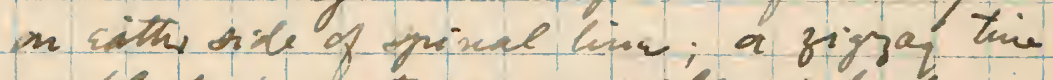
of bladlisk not on muxlle of back and a mene etruight and conthinuoses

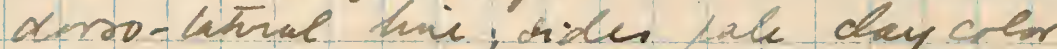
disty and whitisi motred. nuizside ming cale elay-arler, with the sutrais denij Thernh Muplish, lips opotyd mith

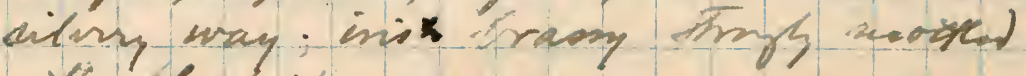
with oluckin 0119. Rimuznathes 4tame ur's ome weribity; sinilury colons. 
0120: Acelopoms nuinlatus o Jug 18. 6 or thosis scomell's ulace, oresniamn Revin, near triblej; Onijs a. 1800 ".

0121. Varfińn 3. Reg 18. ór

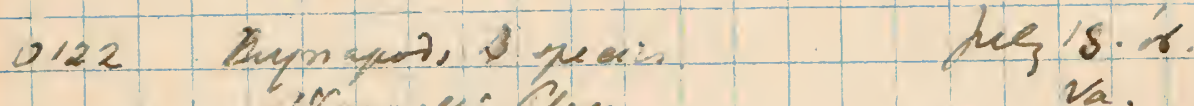

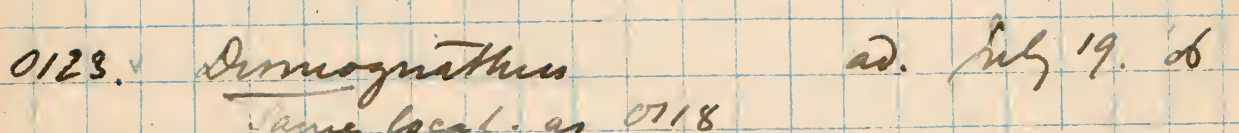
mitarly crlons, thesp omeuteat

0124. Rmanpathen Sug19.06. do.de.
dinalle them ane of the lavine with tranfirmation ans full colons, het the

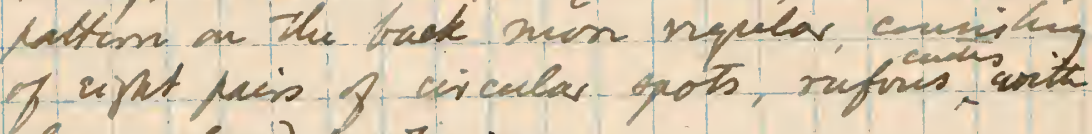
clay colont herifisiss.

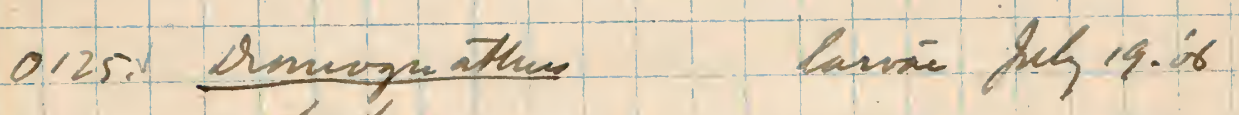

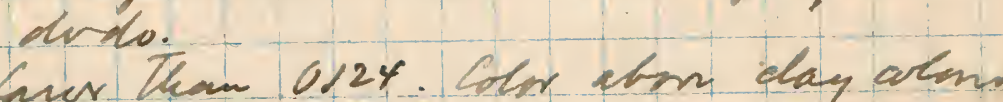

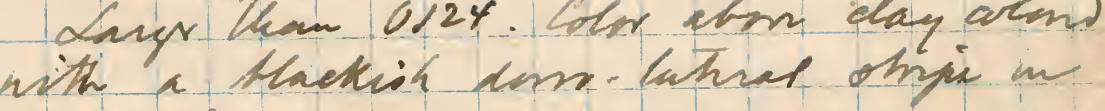
Each side.

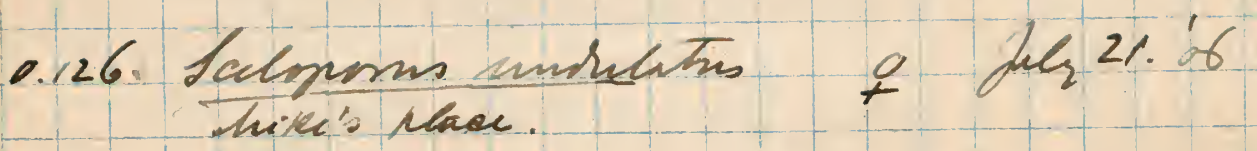

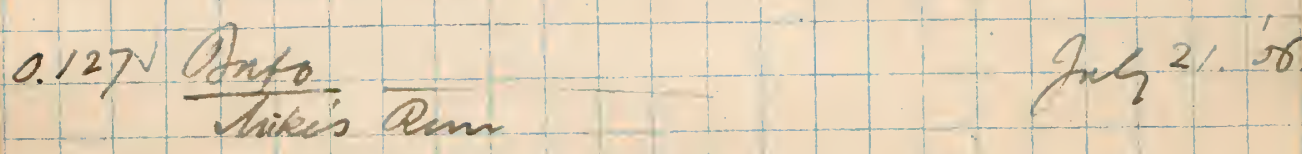





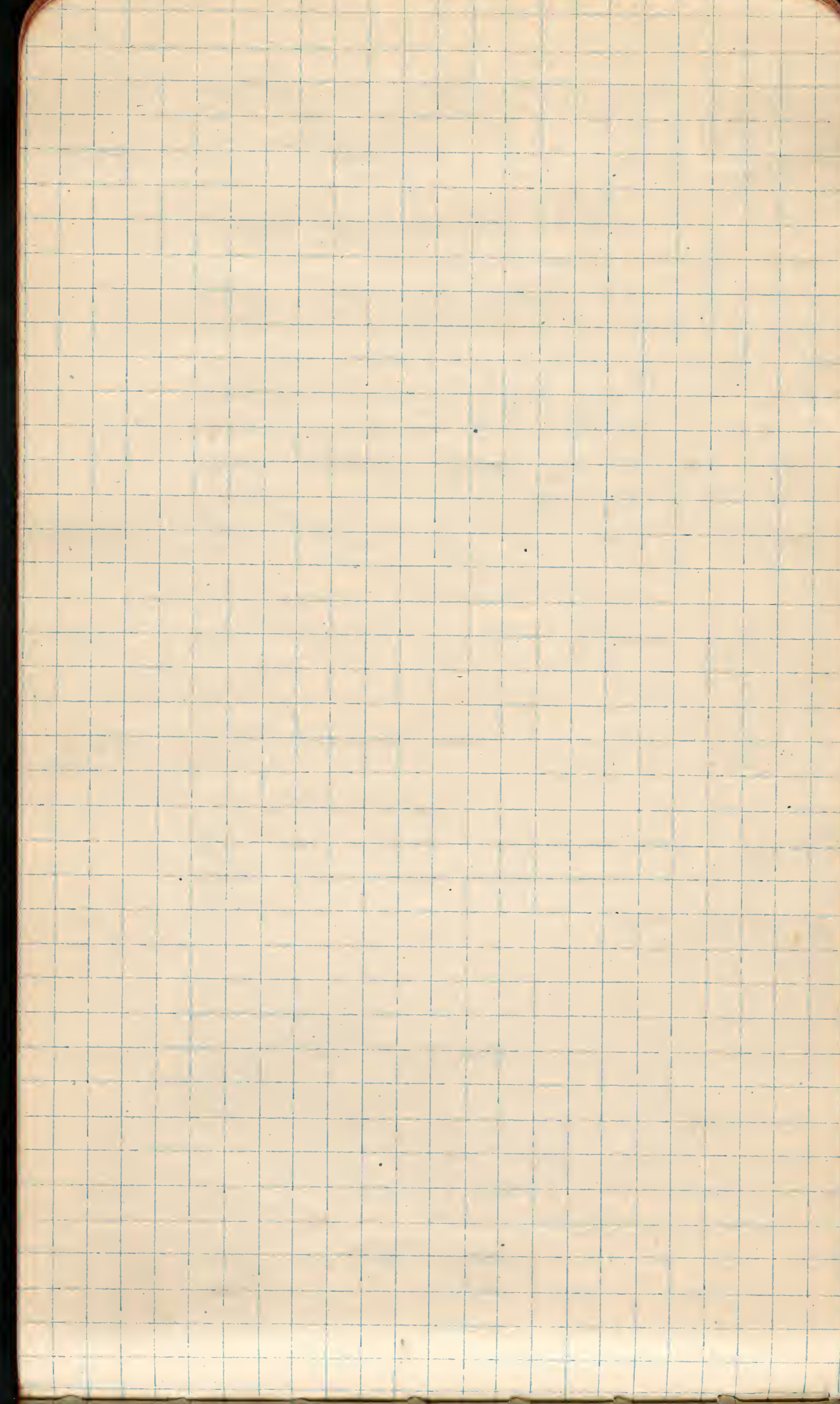

0136:- Pheter:

ina helz2ód do. to.

tials unifun light oypa n brete grarrall ras is 8 vhitise n hll, nidis undestuitfy mover with livk oray

0137. Storaia ocainitimanlata heg 2s'

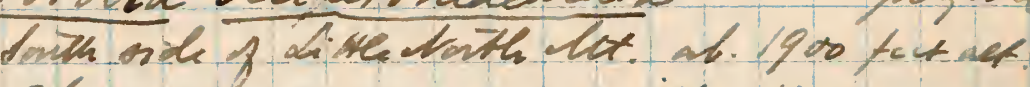
Alove dark pursct unte 4 minow chethout tives; collar oderacenes. antinuone; top of head ocal rum untrozle in lave corat. nd

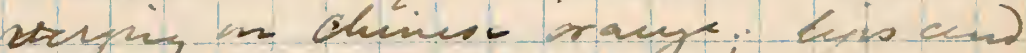
thront white with dnusé tla de quake, iris chentmit.

0138. Dana saluthis or onte ins of or

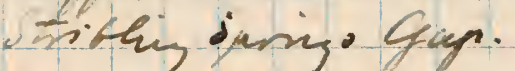

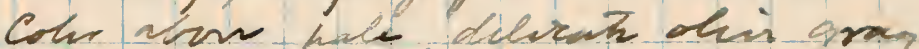
itio deep suntio Inmon cros maste nith equers puthation

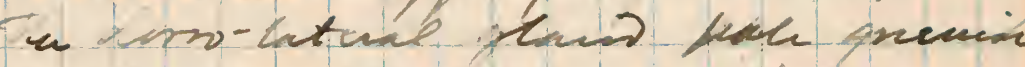
sodern motisions mess of las nefunit with enping nflatanes lice

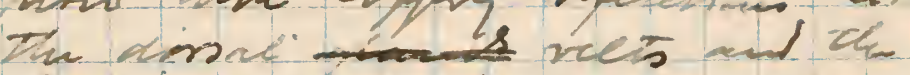

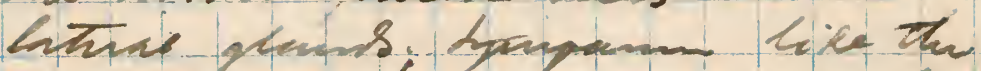

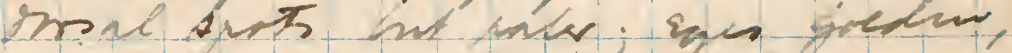
with a vendeis anstic ine n. atom live bade, hot leat ad

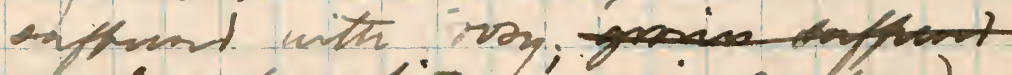
murvide white, gmin onfund with acks yolers.

0.139. Trabphis unctatus hey 2\% or

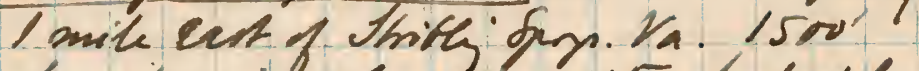

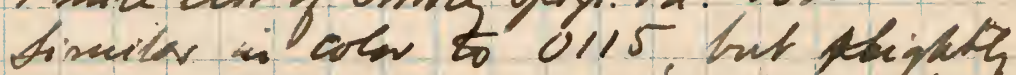

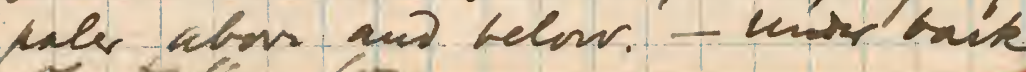
of tabian los 


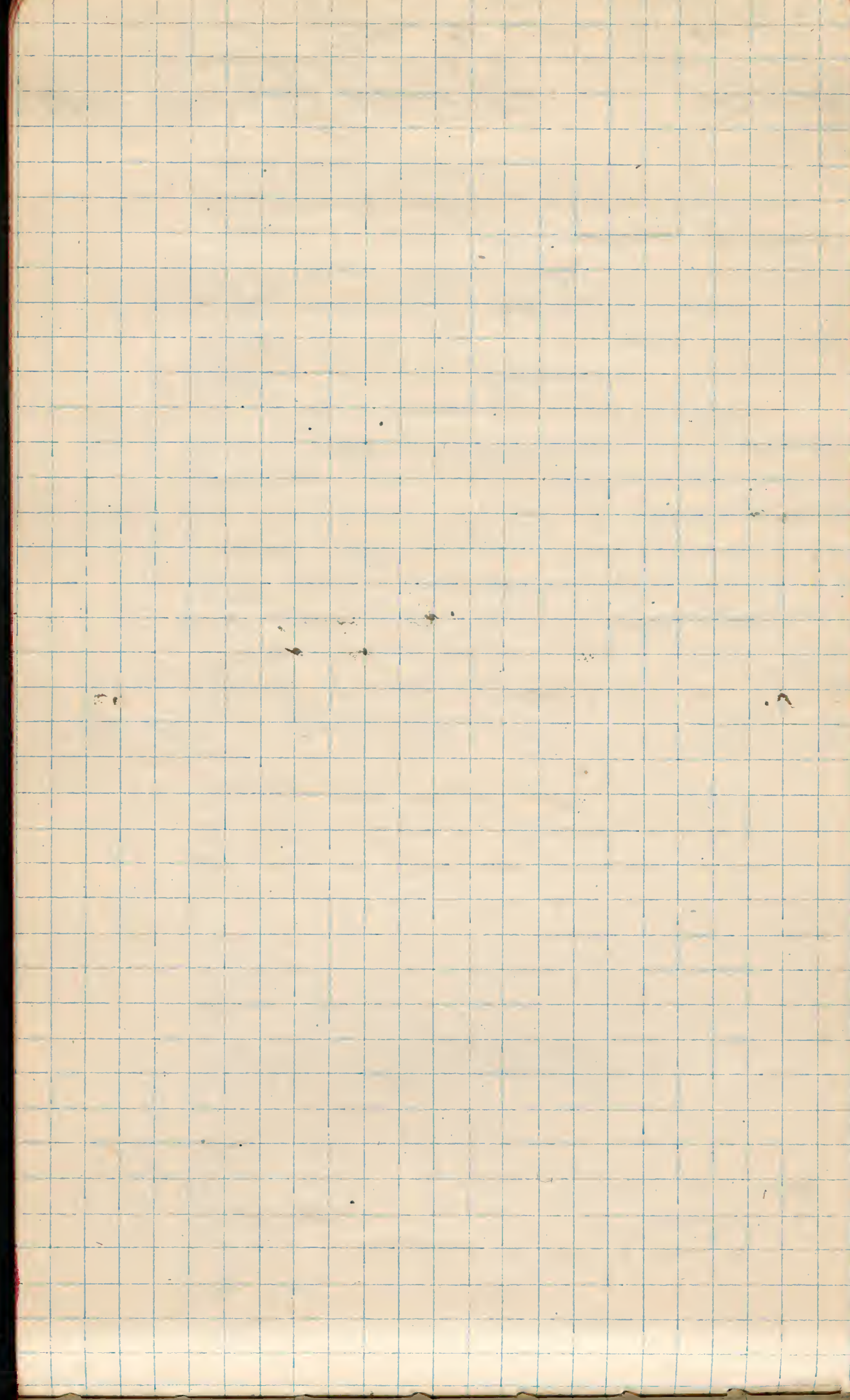

$0140 . \quad \frac{\text { Anfo }}{d_{0}}$ do. abl. her2y id unor loz.

014d Imfo pis uiz2\%.8 under thine.

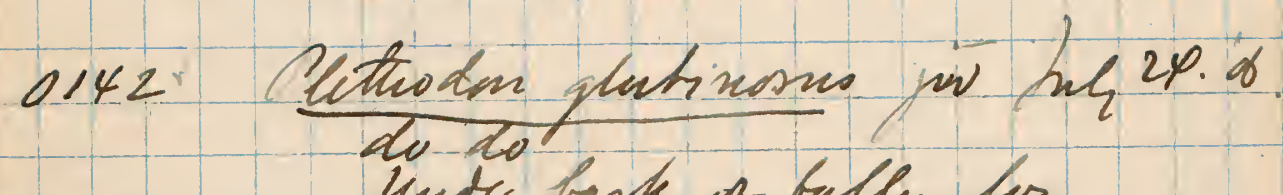
Wute brite of fallen log

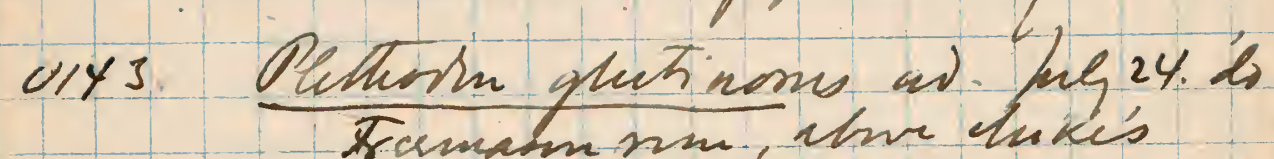
Heace. 16.1750 .

Unori log. 0.144: Dletursm jutinmes ad. Lnk24 id.

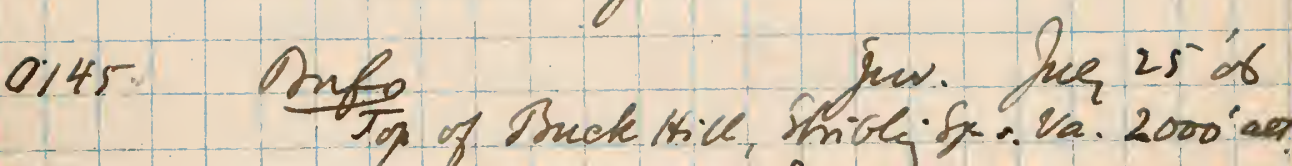
Hoppej an gnnus.

0146 . Minnows, unthont dpersal opst. qonun. Sunde cruste at Mrs. Crome's houses

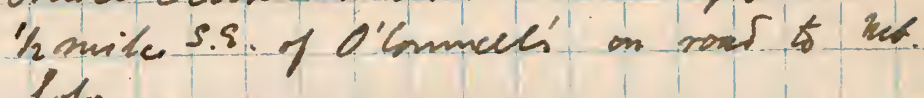
Solon. gne 26 . if

0147. Ronoznathes: a). Gu<26.06 slon mifornul tawn-olin, mith obrane dusty onarbliip, grarkeg faidnin an the sides to the nale qom-dorab of The nutrraide; sides 


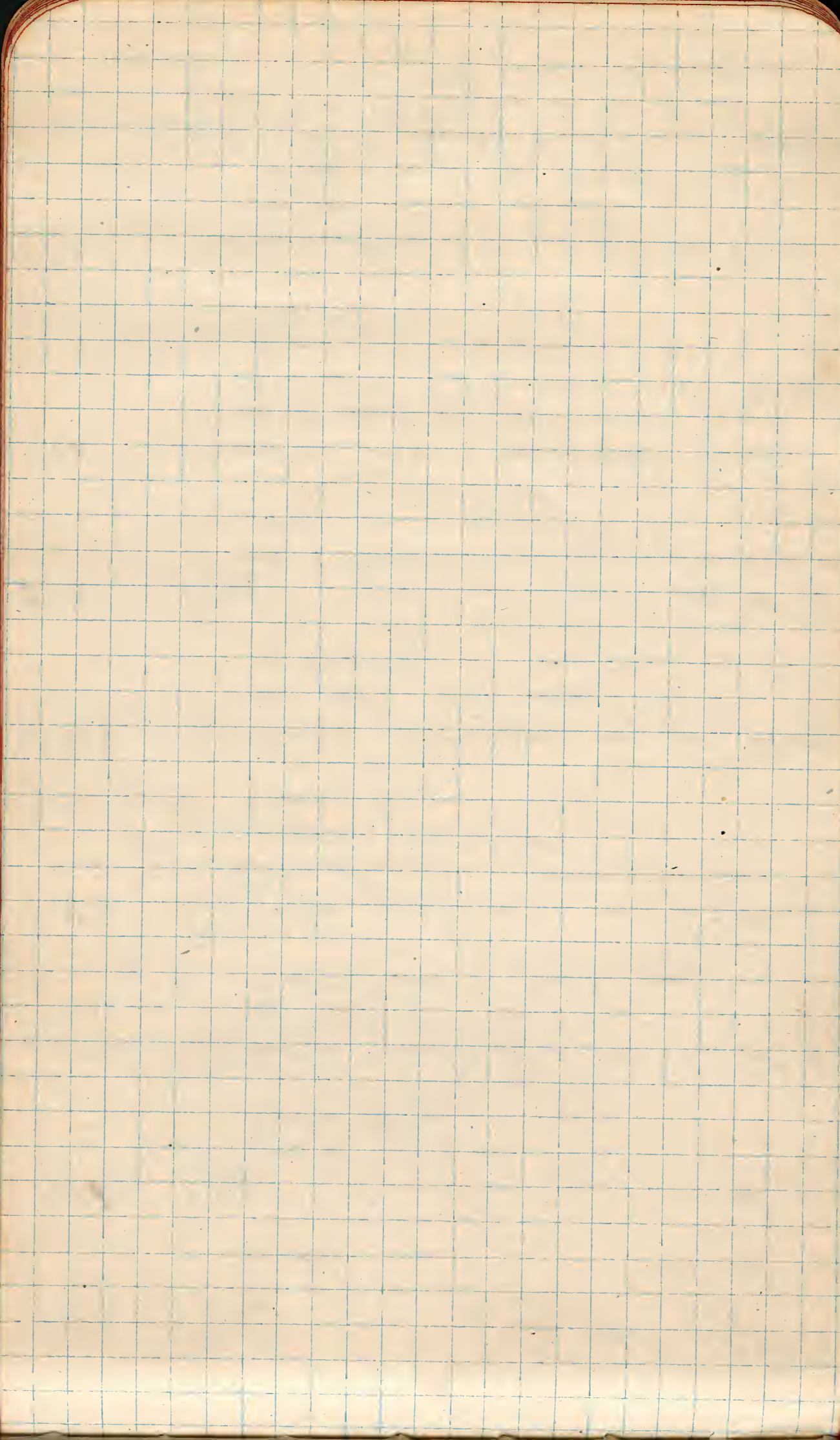

riditind whitish opots, es well as on the lip, an vidisund devity foot. ocular ofreak; ini mixus deurky and

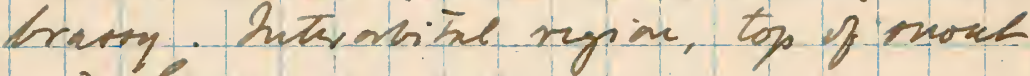
nut lones negre.

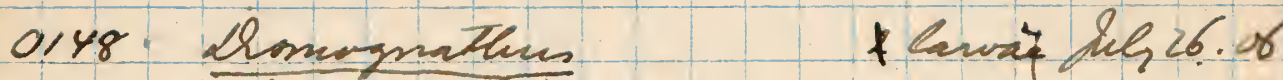
same loc.

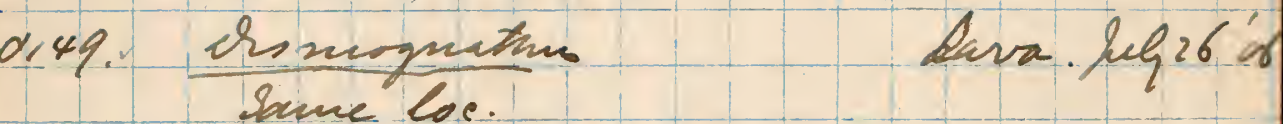
Aborr destey nith nucverons inspla vatur layg taung-deir ogsts.

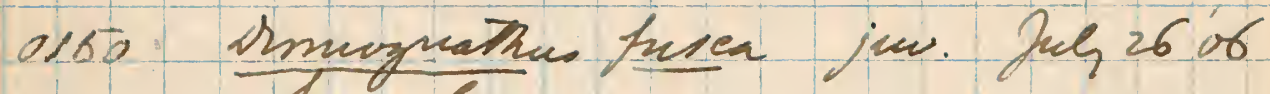
claner lifa 0,23 and 0124.

0151 dropas 1 heg 26 is Sance loe.

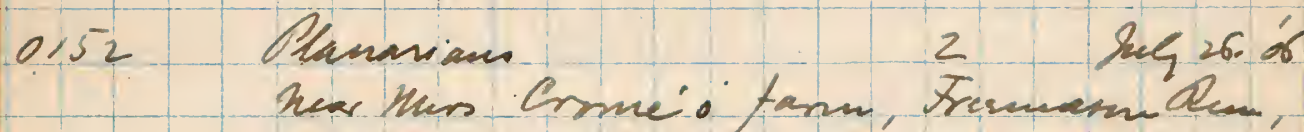
500 act. unire the bask of a pallew lon.

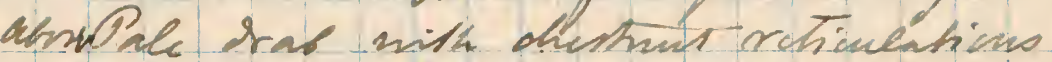

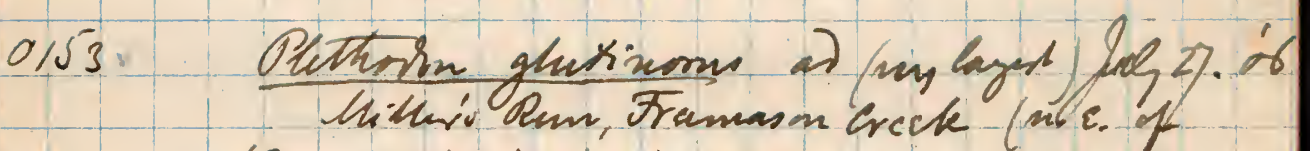
o'enmellifab. $1600^{\circ}$ alt. unter log. - Tail in hinj quanens abnepth pales in teminal half, as if regmerant

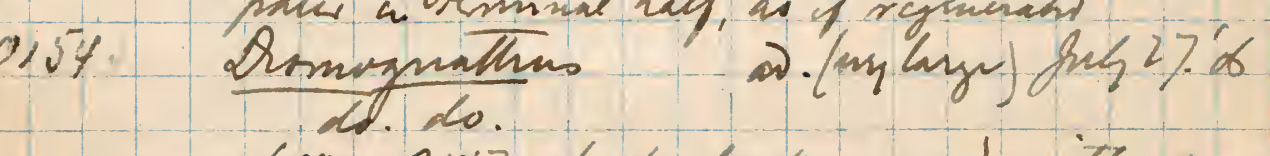
Lim $0 / 4]$, but lanker and with onat

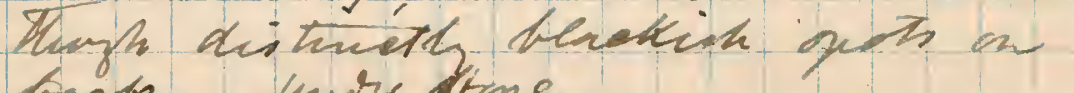
breke. - mirs atme. 


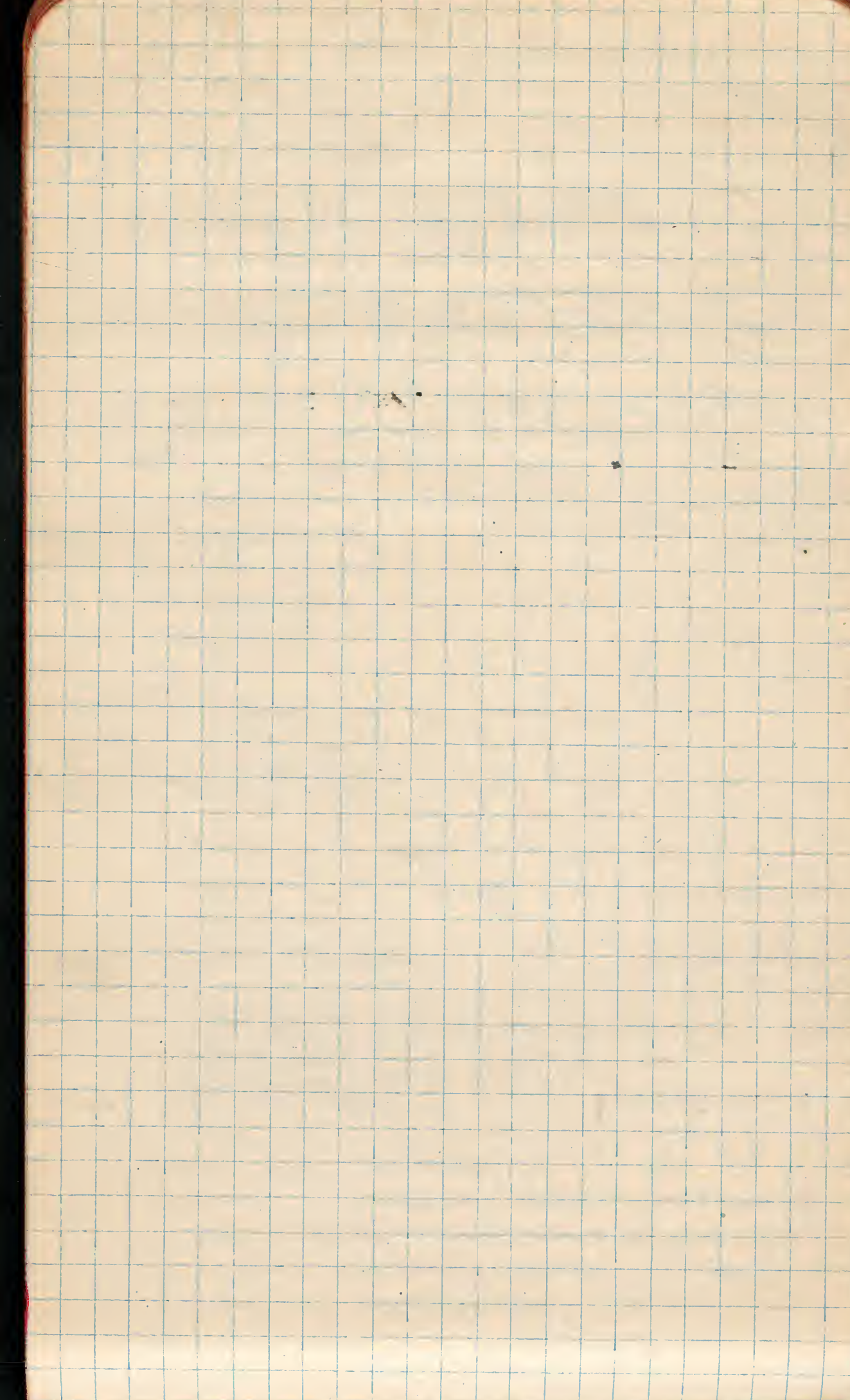

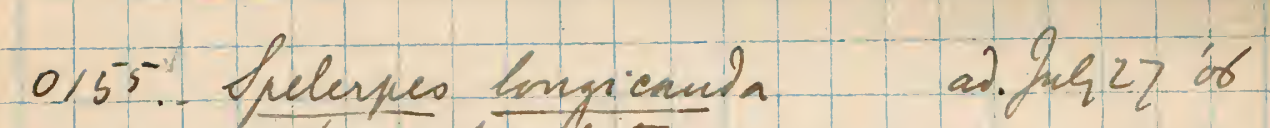

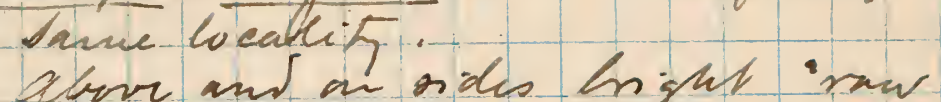
dicunas nale un rmeath. and suffund inta bohe yullew on nomile

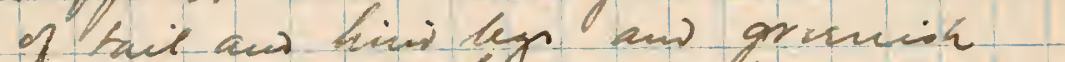
on bul deats beckish, ins bravn

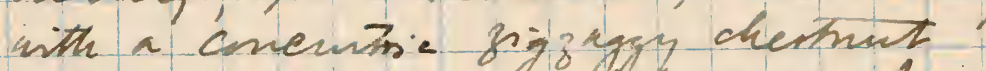
miy ani a duth L Lijon te liametrical live untrode of haus and reet nffiens itte noplish. 0156 Pettorsm glutinom aliful 27. of uner log.

0157 romognathus mea: Jue 27.06 Sarme loeelis 0124 lut th

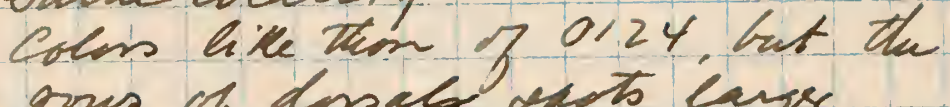

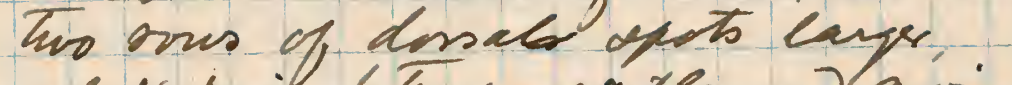
ong 4 pais bovem atril an amin, migs thiskation entisued ar taif. oumal blade operts ntoso of kent; th blade-chel hace min listivet. 0158. Deatharm gutinoris at. Jue 27. oे

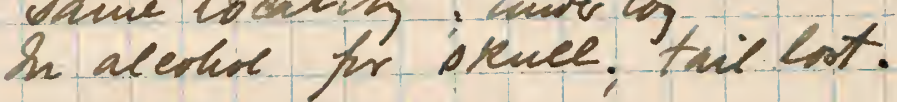

015\%. Thammatis pirtales as Lul 30 in

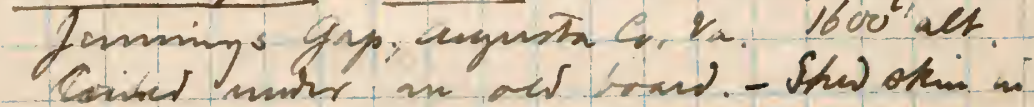

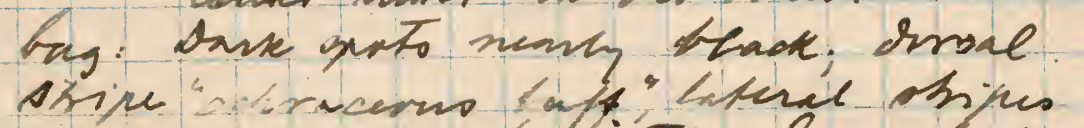
shir buft: stin - Is The lower latarac 



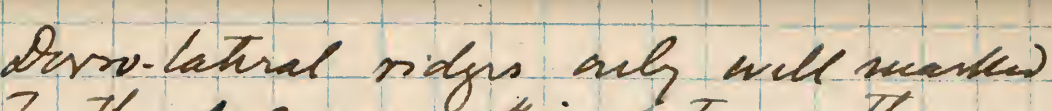
Is the sacreun, okin bstucen then gramear nith Hat tribucles. toss of had onvorth in Strong esits est. 0165

Pma clamitans a).Aug.3. do ame wealis

Sinivila in coler to chore, but oil graen ouffersin al'ment wholly confrees to Che, anpepe lip; $D$ Hnipaune nion cima. mon intr a blactisi esm min and a custine out of oune cler enthastoucteru onotheres of heid ond, gramelar ap curase b) hack un as the lates beeness dirisistly tuberale enf on oxerem.

0166. Aqkistiven centertina qal. Au.4.06 dituia Spming, Mike o'ancll: Hase trivain finjs Na. is. 1750 bet. in the opmin monre, corics at the equig water isones.

016.7 Astistrom entertrie isa) Aug6.ór mor onine cirequntances as iso 0166 , mh that it was nt cerles up.

0168 Amognathen hime Ay 6. of sear is raft, new omens 1800 id. hesieg oides; intorstitas nuace erassow. 2lunai AgGoór same exelis. 


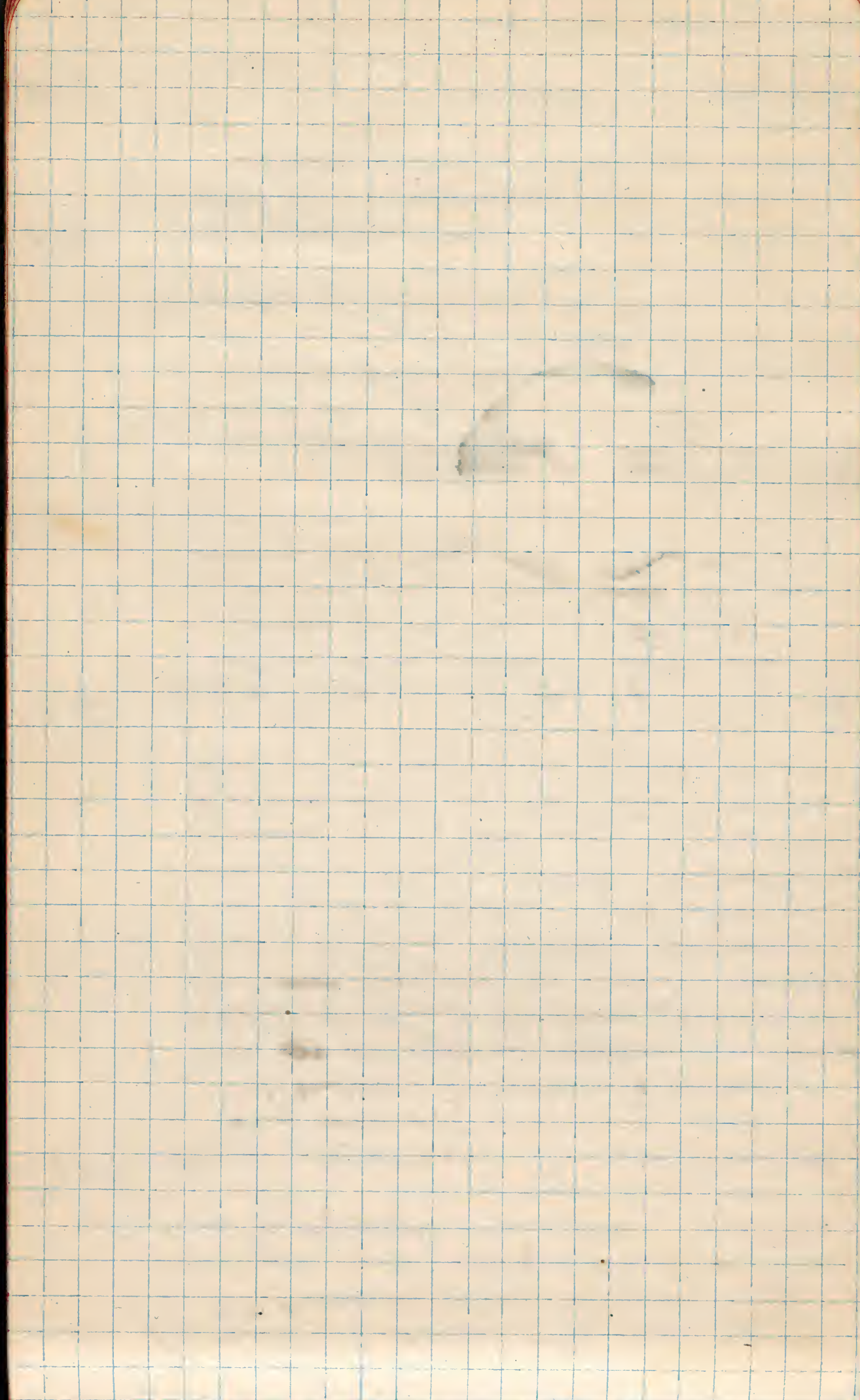

White ens, and gosups of fens n head. Interostitit opace iside nuveh unider than iges.

Q170 Deass Araft, afmet 1800' ener baike of fallen log.

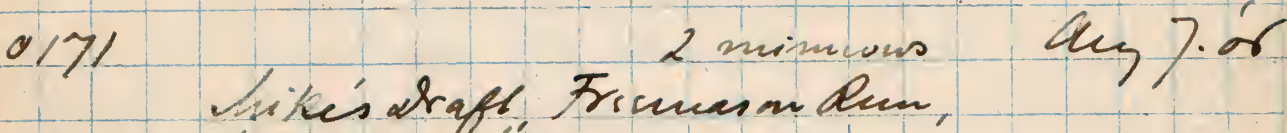
below der honere.

In dees furol.

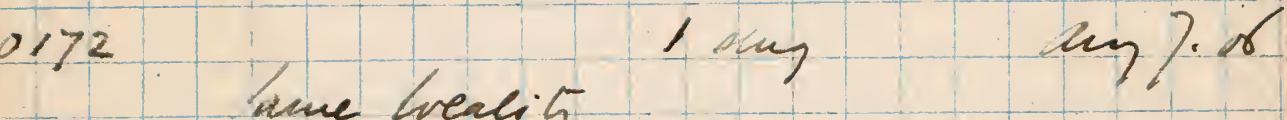
muter otme

067 Inue localit 2 Carite An 7.80

0174. Pane clenitans Aug 8. of Fremesen num (main) halfury. bettruendeites and Stoken nille, 1500 Linilar in coler $80165^{\circ}$ hit mittem Wurtey min ac cutts to zompancen Drex mis whole top If haw nealy tubreces on tide large.

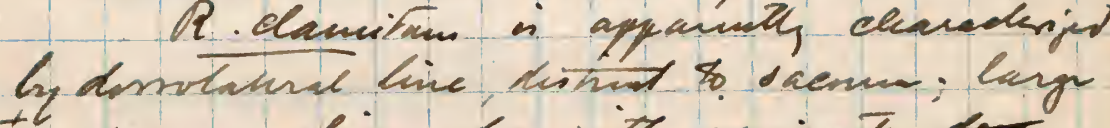

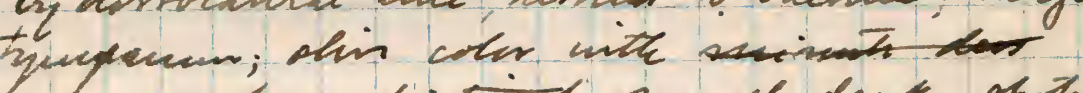
nim or lin distid onall deerky opito gramulas dirsinitgricinglabial bant.

0,75

nothes

Same banti5. 


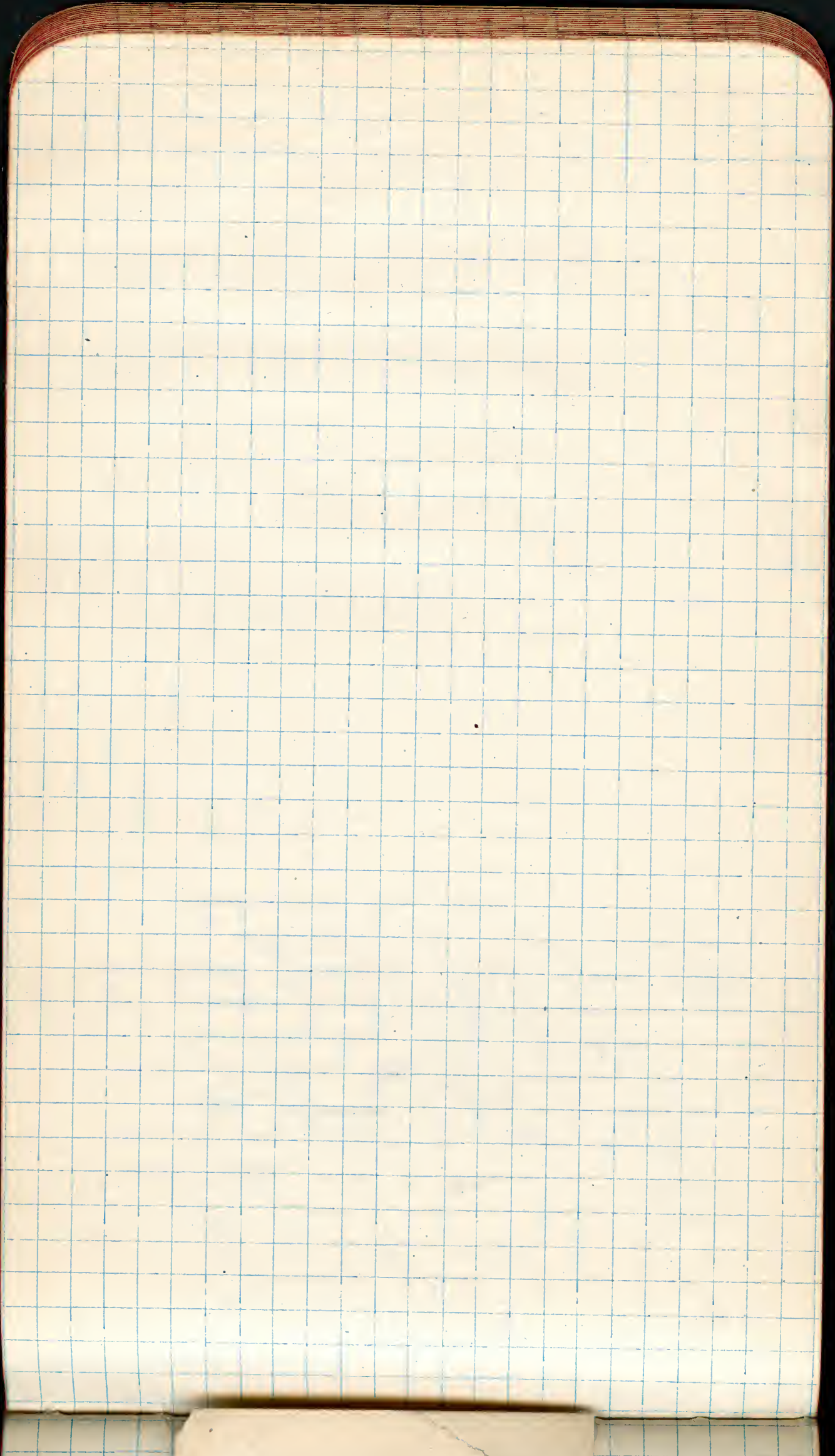

Family ENGY: The Eng

IAWS without tee $\int$ firmisternian and cesses dilated.

Widely "distributer portions of the globe, the United States, c little Carolina Frog, ense. Most of the some burrow in the aquatic, but none are 


\section{Family ENGY The Eng}

TAWS without tee firmisternian and cesses dilated. Widely "distributed portions of the globe, the United States, d little Carolina Frog, ense. Most of the some burrow in the aquatic, but none are 
$1905-1906$

Collections in

marefe t 4. 8 


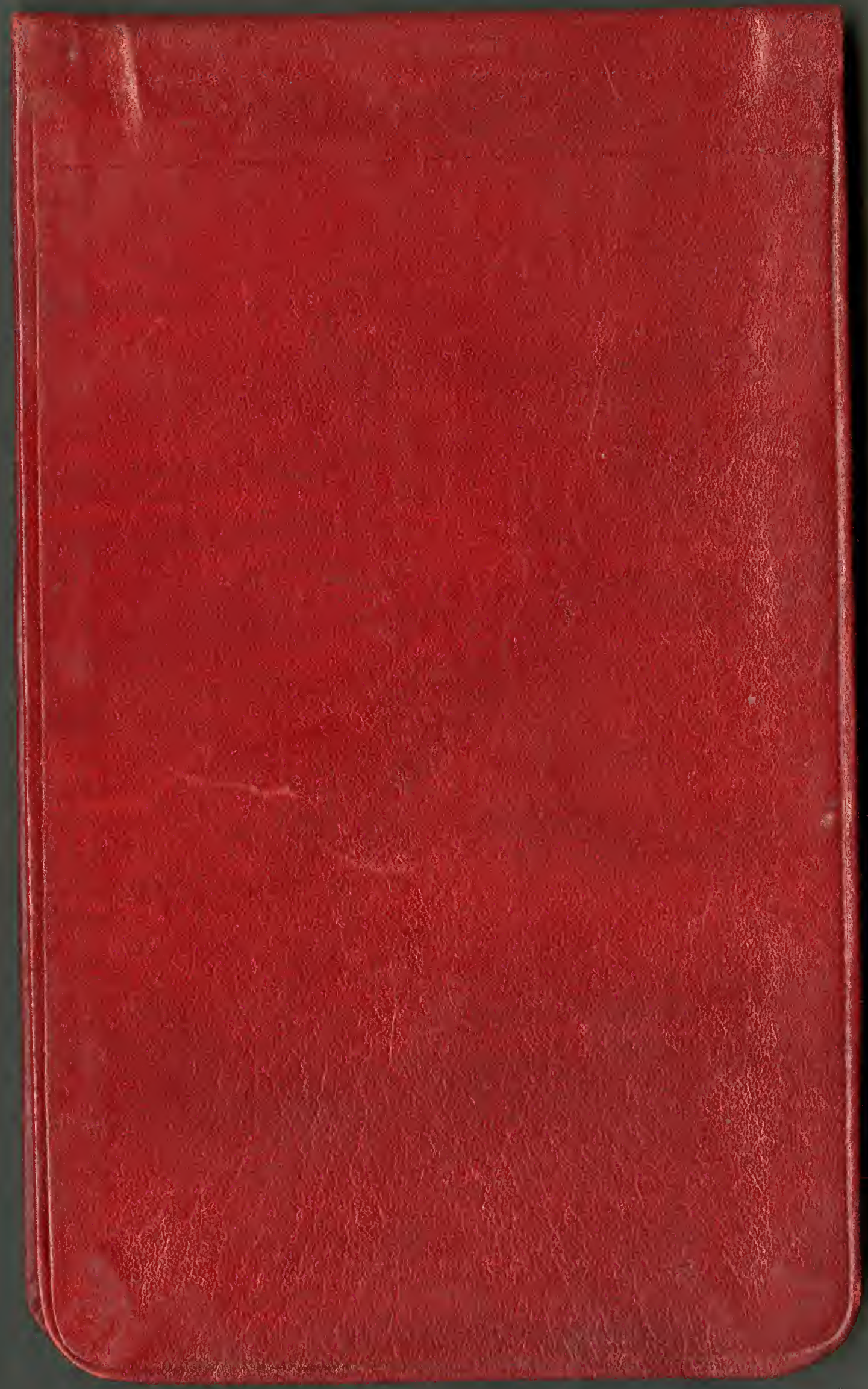

